\title{
OCCURRENCE AND CHARACTERIZATION OF ENTOMOGEN GALLS IN PLANTS FROM NATURAL VEGETATION AREAS IN DELFINÓPOLIS, MG, BRAZIL
}

\author{
URSO-GUIMARÃES, M. V., ${ }^{1}$ SCARELI-SANTOS, C. ${ }^{2}$ and BONIFÁCIO-SILVA, A. C. ${ }^{3}$ \\ ${ }^{1}$ Departamento de Biologia, FFCLRP/USP, Av. Bandeirantes, 3900, CEP 14900-401, Ribeirão Preto, SP, Brazil \\ ${ }^{2}$ Departamento de Ecología de los Recursos Naturales, Instituto de Ecología, UNAM, Campus Morelia Antigua \\ Carretera a Pátzcuaro, n. 8701, Col. Ex-Hacienda de San José de la Huerta, C.P. 58190, \\ Morelia, Michoacán, México \\ ${ }^{3}$ Programa de Pós-graduação em Biologia Comparada, FFCLRP/USP, Av. Bandeirantes, 3900, \\ CEP 14900-401, Ribeirão Preto, SP, Brazil \\ Correspondence to: Maria Virgínia Urso-Guimarães, Departamento de Biologia, FFCLRP/USP, \\ Av. Bandeirantes, 3900, CEP 14900-401, Ribeirão Preto, SP, Brazil, e-mail: mvirgini@usp.br \\ Received September 13, 2002 - Accepted November 20, 2002 - Distributed November 30, 2003
}

(With 24 figures)

\begin{abstract}
In the present work we aimed to register the occurrence of galls, inductors, inquilines, and parasitoids in plants of three natural vegetation areas in Delfinópolis, MG, Brazil. Results obtained showed 22 types of galls collected from leaf, vein leaf, petioles, stem, and inflorescence of nineteen species belonging to fifteen distinct families. Concerning gall morphology, the following were collected: globoid, conicle, discoidal, fusiform, shell-shape, indefinite, and one substituition of an ovary by an immature. As principal inducers were found insects of the families Cecidomyiidae (Diptera), Psyllidae, and Diaspididae (Sternorrhyncha/ Hemiptera). As parasitoids the most common are of the Chalcidoidea superfamily (Hymenoptera) and, as occasional inquilines, Polyxenidae (Diplopoda) and Psocodea (Psocoptera). The results of this study contribute to existing of knowledge host-plant diversity and gall-associated insects in rocky fields, cerrado, and gallery forests.
\end{abstract}

Key words: galls, insect gall maker, cerrado, rocky fields, Brazil.

\section{RESUMO}

\section{Ocorrência e caracterização de galhas entomógenas em plantas de áreas de vegetação natural em Delfinópolis, MG, Brasil}

Neste trabalho registramos a ocorrência de galhas, galhadores, inquilinos e parasitóides em plantas de três áreas de vegetação natural em Delfinópolis, MG, Brasil. Como resultado foram obtidas galhas coletadas em folhas, nervuras de folhas, pecíolos, ramos e inflorescências de quinze famílias distintas. Quanto à morfologia, foram coletadas galhas globóides, cônicas, discóides e fusiformes, em forma de concha, uma sem formato definido e uma substituição do ovário pelo imaturo. Como principais indutores foram obtidos insetos das famílias Cecidomyiidae (Diptera), Psyllidae e Diaspididae (Sternorrhyncha/Hemiptera). Os parasitóides são da superfamília Chalcidoidea (Hymenoptera) e, como inquilinos ocasionais, Polyxenidae (Diplopoda) e Psocodea (Psocoptera). Os resultados deste trabalho contribuem para aumento do conhecimento sobre a diversidade de plantas hospedeiras e insetos galhadores associados à vegetação de campo rupestre, cerrado e mata de galeria.

Palavras-chave: galhas, inseto galhador, cerrado, campo rupestre, Brasil. 


\section{INTRODUCTION}

A galls is a pathologically developed vegetal tissue originating mechanically or chemically in stimulation of inductor agents. The process can be classified as hypertrophic or hyperplastic depending on the case. According to Mani (1964), these types develop through interaction of host plant and inducer, a hypothesis defended also by Abrahamson \& McCrea (1986), who proposed that gall phenotype is a result of interaction between two genotypes. The first is of the inducer, for the stimulus, the second is of the host plant, for the reaction. In this way, it is expected that different gall makers produce different gall types in the same host. Gullan \& Cranston (1994), and Hartley (1998), among other authors, defended this hypothesis, highlighting a complex specificity in the interacting gall makerhost plant. The high level of specificity of the gallmaker and host-plant association have been commented on by many authors (Mani, 1964; Abrahamson et al., 1998) and is regarded as one of the better systems for critically evaluating coevolution of involved organisms (Abrahamson \& McCrea, 1986).

Other authors have performed studies involving occurrence and characterization of galls in diverse environments. Occhioni $(1979,1981)$ obtained 35 types of galls in 34 families of plants in the restinga environment; Fernandes et al. (1988, 1997) related the occurrence of galls and their characterization in Brazilian cerrado and rocky field plants, and Scarelli-Santos \& Urso-Guimarães (submitted) found 37 galls in 16 families of plants in cerrado vegetation. In Brazil, the principal host plants of insect galls belong to the Asteraceae, Fabaceae, Myrtaceae, and Anonnaceae families.

The present work aimed to morphologically describe galls, with mention of the inducers, so as to increase the knowledge about the diversity of galls and gall makers in three distinct areas of natural vegetation in Delfinópolis, MG, Brazil.

\section{Physical characterization of the region}

The Delfinópolis region is located in Minas Gerais State, southeastern Brazil (46 $45^{\circ}$ ' $-47^{\circ} 00^{\prime} \mathrm{W}$ and $20^{\circ} 15^{\prime}-20^{\circ} 30^{\prime} \mathrm{S}$ ), in the area surrounding Represa de Peixoto of the Rio Grande River. It is situated geomorphologically in Patamares da Canastra (the Canastra mountain range area), with altitudes varying from 600 to 1200 m (EMBRAPA,
1999). The climate is Cwa type, being temperate rainy and hot $(C)$ with summer rains $(w)$, the average temperature in the hottest month reaching more than $22^{\circ} \mathrm{C}$ (a) (Köppen classification). The average annual rainfall is higher than $1630 \mathrm{~mm}$, mainly between December and January with average rainfall indices of $100 \mathrm{~mm}$; the driest period is from May to August with average precipitation of less than $40 \mathrm{~mm}$ (Nimer, 1989).

\section{Studied vegetation}

Minas Gerais presents a complex mosaic composed of forest areas, cerrado, high grassland, and rocky fields. These latter two are associated with the shallow soil of the highest points of the local mountains, whereas occur cerrado and forest in the deepest soils which is fertile, with abundant ground water (Eiten, 1982, apud Oliveira-Filho et al., 1994).

The cerrado (Brazilian savannah) is a type of vegetation varying in physiognomy, ranging from fields with a cover of sparse brush and low trees to forest formations, with trees of heights from 12 to $15 \mathrm{~m}$ (Fig. 1). The herbaceous stratum is mostly composed of grasses which are bushy and and dicotyledonous, but present neither rose-like plants, nor succulent or spiny ones. Only a few lianas and epiphytes are present (Rizzini, 1979). The cerrado occurs on reddish-yellow, dark red, and purple latosol which is strongly or moderately acid, with $\mathrm{pH}$ varying between 4.5-5.5 (Ribeiro \& Walter, 1998). The families Fabaceae, Asteraceae, Myrtaceae, Melastomataceae, and Rubiaceae are the most common in this region (Batalha \& Mantovani, 2000).

Gallery forests (Fig. 2) accompany small rivers, forming a closed corridor in watercourses above the water stream, and usually occur on valley bottoms or in drainage areas. They may also be present in transitions between initial formations of cerrados and fields. Concerning floristic composition, both types commonly belong to the following families: Myrtaceae, Leguminosae, Vochysiaceae, Rutaceae, Meliaceae, and Rubiaceae (van den Berg \& Oliveira-Filho, 2000; Bertani et al., 2001).

The rocky fields (Fig. 3) are characterized by a continuous herbaceous stratum, made up mainly of Graminae, Eriocaulaceae, Xyridaceae, and Cyperaceae, as well as areas where some bushy forms also appear, specially representatives of the families Velloziaceae, Asteraceae, Melastomataceae, Malpighiaceae, Myrtaceae, Fagaceae, and Vochysiaceae (Giulietti et al., 1987). 

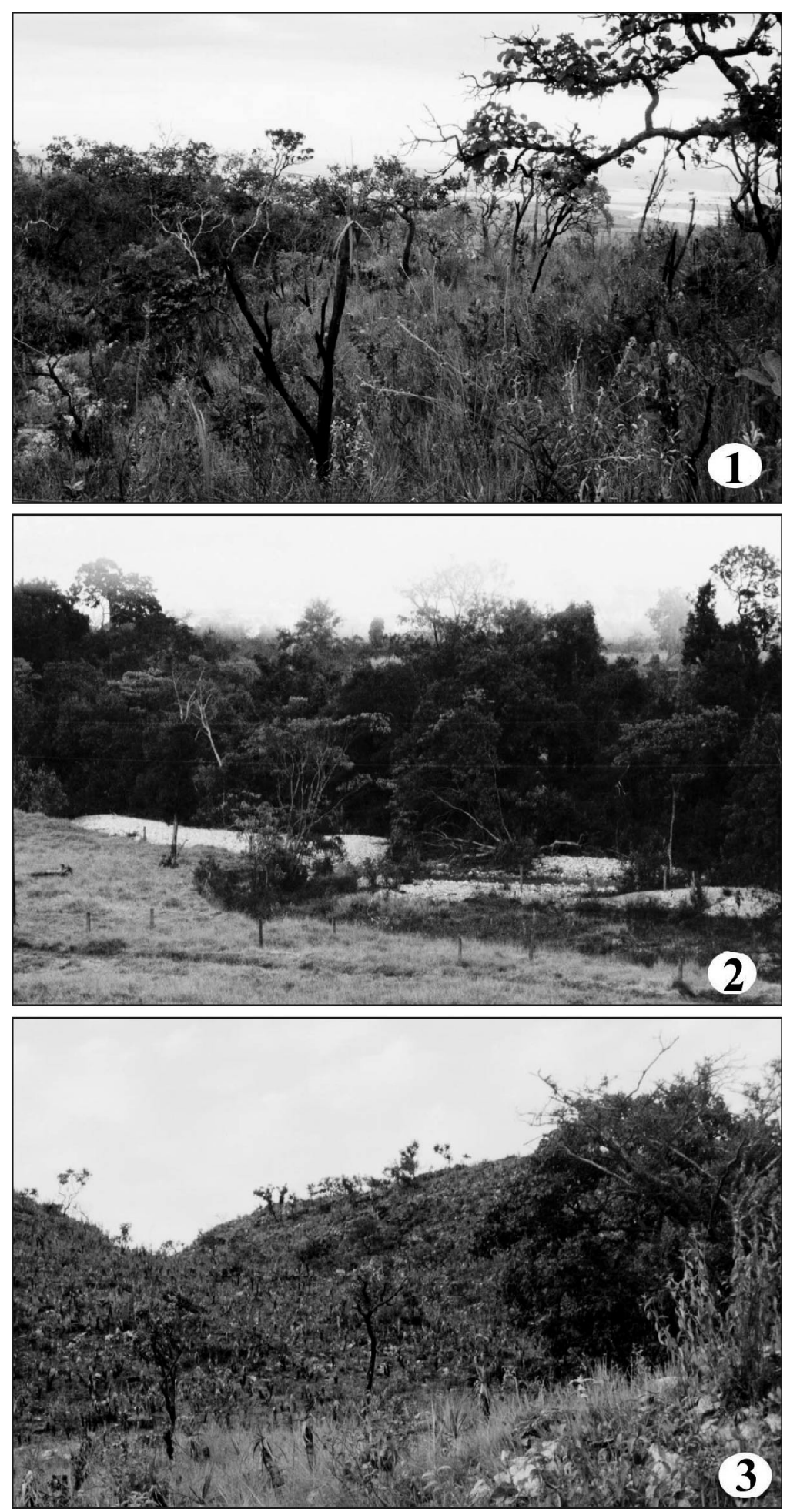

Figs. 1-3 - General view of the environment studied. Fig. 1 - Cerrado. Fig. 2 - Gallery forest. Fig. 3 - Rocky field. 
These occur in regions where the altitude may vary from 700 to $1000 \mathrm{~m}$ and the plants are subject to constant wind, hot daylight, and cool nights; they are usually found in latosol in condition of low water availability. What water is present is quickly drained into the surrounding rivers, due to shallow depth and reduced water-retention capability of local soil (Ribeiro \& Walter, 1998).

\section{Treatment of samples}

The host plant samples were collected following the Fernandes et al. (1988) methodology, photographed, stored, and labeled in plastic bags. In the laboratory, morphological descriptions and specimen identification were made. Part of the material was immersed in plastic pots filled with water and closed with a net in order to obtain inductors, parasitoids, and inquilines. All material was conserved in $70 \%$ alcohol. Slide mounting of gall maker specimens for identification followed the Gagné (1994) technique. Samples were collected from March to September of 2000 in rocky field, cerrado, and gallery forest areas.

The vouchers of host plants were deposited in the Botanical Sector, and the gall and insect collection is located in the Laboratory of Invertebrates, both in the Biology Department, Faculdade de Filosofia Ciências e Letras de Ribeirão Preto, Universidade de São Paulo, Brazil.

\section{RESULTS AND DISCUSSION}

Results are presented in Table 1 which gives the morphological description of galls per host plant, gall makers, and parasitoids. Galls were observed in nineteen plant species, listed in Table 1 and shown in Figs. 4 to 24. Results are also presented in Appendix 1 which shows all the information about collection points and collected material.

In our collections, $79 \%$ of galls were found on leaves, $8 \%$ on stems, $8 \%$ on petioles, $4 \%$ on inflorescences, and $4 \%$ on bud leaf. The morphological types of galls found were globoid, conicle, discoidal, fusiform, shell-shape, and indefinite, with color varying from green to reddish-brown. Concerning the surface where galls were located on leaf, $64.58 \%$ of galls are found on the adaxial and $7.14 \%$ on the abaxial surfaces, with $28.58 \%$ on both sides. The majority of the sampled galls are hairy and the spherical gall of $T$. guianensis
(Anacardiaceae) is glabrous on its adaxial surface and pubescent on its abaxial surface (Fig. 4). Fernandes et al. (1997) state that the hair and spine protect the inducer inside the gall against parasitoids, although all hairy galls found in Delfinópolis had an associated parasitoid.

The majority of plant species presented only one morphological type of gall. The exceptions were B. ungulata (Fabaceae) with a leaf (Fig. 13) and a stem gall (Fig. 14); C. pohliana (Rubiaceae) with one hairy gall in the leaf and another the in stem (Fig. 21); and Q. parviflora (Vochysiaceae) with two different types of galls on its leaves: one discoidal, occurring along the main leaf vein (Fig. 23), and the other fusiform with spines (Fig. 24). The occurrence of distinct morphological types of galls in the same plant species is rather common. For example, Fernandes et al. (1996) found 17 distinct kinds of galls in Baccharis dracunculifolia, and Gonçalves-Alvin \& Fernandes (2001) described four types of galls in Byrsonima coccolobifolia (Malpighiaceae) and three on Eriotheca gracilipes (Bombacaceae).

Comparing the three vegetation physiognomies studied so far, the gallery forest and Brazilian cerrado showed more plant species with galls than did the rocky field. These results can be explained by fact that plant diversity is higher in the cerrado and gallery forest than in rocky fields. Most articles about the incidence of galls associate their occurrence with hygrothermic stress (Fernandes \& Price, 1991). According to the latter authors, in hygrothermically stressed environments such as cerrado and rocky field, the appearance of galls tends to be much more common. Our results neither confirm nor corroborate this hypothesis because the collections were not made for purposes of comparison.

According to Rohfritsch \& Shorthouse (1982), approximately 15,000 gall inductor insects are listed worldwide; they belong to the Thysanoptera, Lepidoptera, Coleoptera, Hymenoptera, Hemiptera (Sternorrhyncha), and Diptera Orders. Of these, the Diptera, especially the Cecidomyiidae family, is the most representative numerically. In Delfinópolis, we were able to confirm this fact, with Diptera inducing $59 \%$ of galls, $54 \%$ of which were of the Cecidomyiidae family; $9 \%$, of the Sternorrhyncha (Hemiptera); and 27\%, of unidentified inducers. 

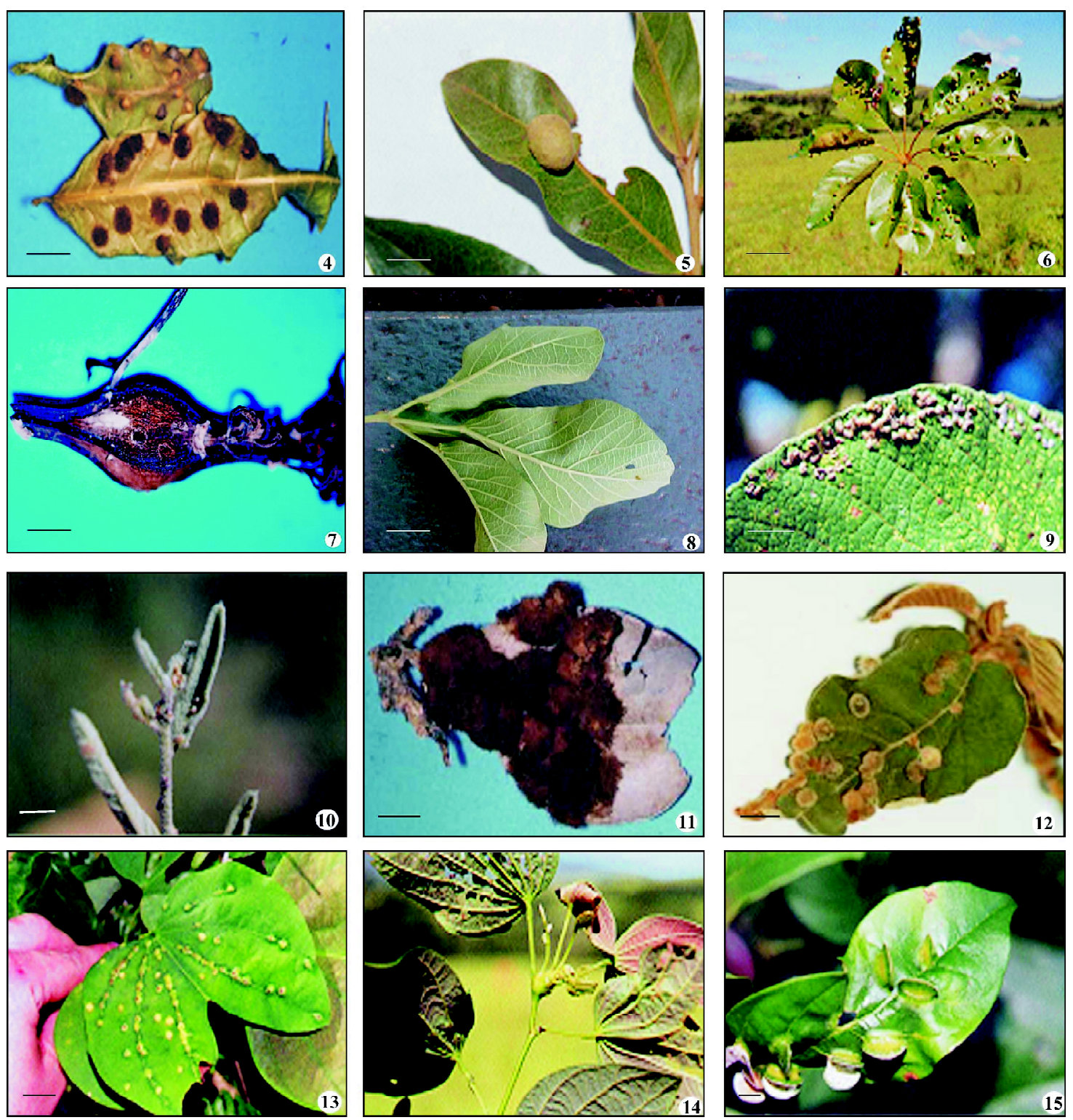

Figs. 4-15 - Host plants and their galls in Delfinopolis. Fig. 4 - Tapirira guianensis (Anacardiaceae). Fig. 5 - Duguetia furfuraceae (Annonaceae). Fig. 6 - Didymopanax morototoni (Araliaceae). Fig. 7 - Vernonia polyanthes (Asteraceae). Fig. 8 - Tabebuia ochraceae (Bignoniaceae). Fig. 9 - Caryocar brasiliense (Caryocaraceae). Fig. 10 - Merremia tomentosum (Convolvulaceae). Fig. 11 - Erythroxylum daphnites (Erythroxylaceae). Fig. 12 - Croton floribundus (Euphorbiaceaae). Figs. 13 and 14 - Bauhinia ungulata (Fabaceae). Fig. 15 - Lonchocarpus guilleminianus (Fabaceae). Fotos: Urso-Guimarães \& Scareli-Santos.

The Cecidomyiidae are a large family of Diptera with around 15.000 described species. About 95\% of this total belongs to the Cecidomyiinae subfamily, composed exclusively of gall makers. As in many natural environments in the neotropical region, almost all insects collected as gall inducers are new to science. In the three types of natural vegetation sampled in Delfinópolis, we collected 12 new species of Cecidomyiidae, two of which are also new genera (see Table 1). All new species and genera are described in other works, such as the description of Asphondylia canastrae, collected in ovaries of Leonotis nepetifolia (Lamiaceae) (UrsoGuimarães \& Amorim, in press). 

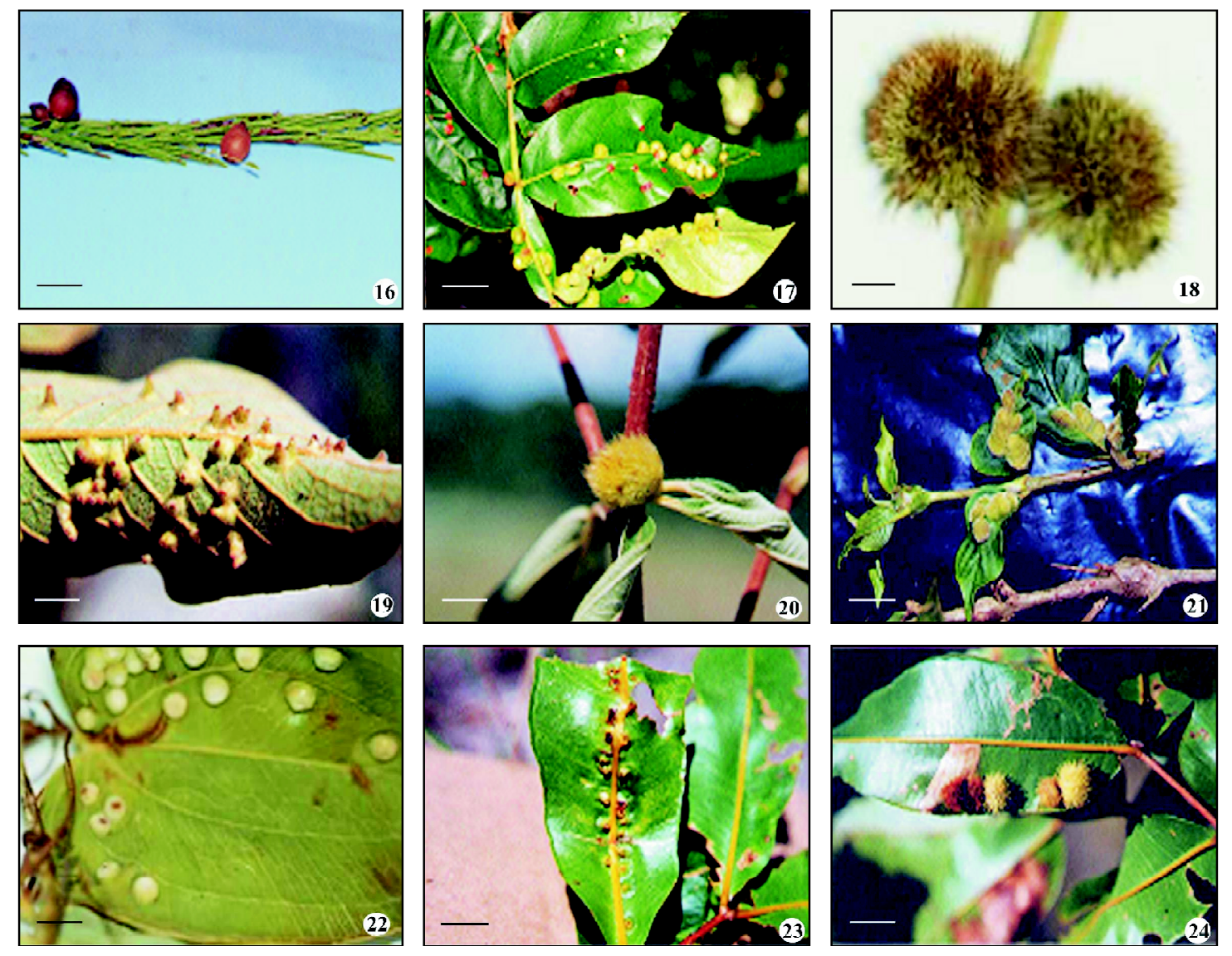

Figs. 16-24 - Host plants and their galls of Delfinópolis. Fig. 16 - Anadenanthera macrocarpa (Fabaceae). Fig. 17 - Inga edulis (Fabaceae). Fig. 18 - Leonotis nepetifolia (Lamiaceae). Fig. 19 - Byrsonima sericeae (Malpighiaceae). Fig. 20 - Macaiera radula (Melastomataceaae). Fig. 21 - Chomelia pohliana (Rubiaceae). Fig. 22 - Smilax coriifolia (Smilacaceae). Figs. 23 and 24 - Qualea parviflora (Vochysiaceae). Fotos: Urso-Guimarães \& Scareli-Santos.

The new genera and new species belong to the Lopesiini and Alycaulini tribes. The new species already identified belong to Neolasioptera (3 sp.) and Contarinia (1 sp.) genera. The six other inducers of the Cecidomyiidae family are being studied.

Fernandes et al. (1988) related the presence of galls of Tomoplagia rudolphi (Tephritidae) in Vernonia polyanthes (Asteraceae), as well as a species of Psyllidae in Lonchocarpus guilleminianus (Fabaceae), also found in Delfinópolis. This fact shows that gall makers are very specific to a given ecological niche, and such specificity might be related to one genus or even to a single species. Most parasitoids found in Delfinópolis belong to the Chalcidoidea superfamily (Hymenoptera): Eulophinae
(Eulophidae), Spalangiinae (Pteromalidae), Toryminae (Torymidae), and Rileynae (Eurytomidae). The others are from Helconinae and Microgastrinae (Braconidae). The Chalcidoidea includes the most common wasp parasitoids known and are largely found in galls of cecidomiids. As an inquiline, one new species of Meunieriella (Diptera: Cecidomyiidae) was obtained from Inga edulis galls. Meunieriella is an inquiline in ex-galls of other cecidomiids (Gagné, 1994). Other occasional inquilines obtained were a species of Polyxenus (Diplopoda: Polyxenidae) and a species of Psocodea (Psocoptera) both in Smilax coriifolia (Smilacaceae). Some immatures of Aphididae and Lygaeidae (Hemiptera) were also found. 

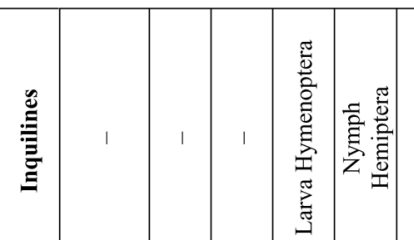

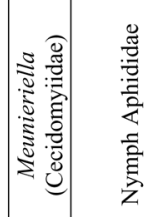

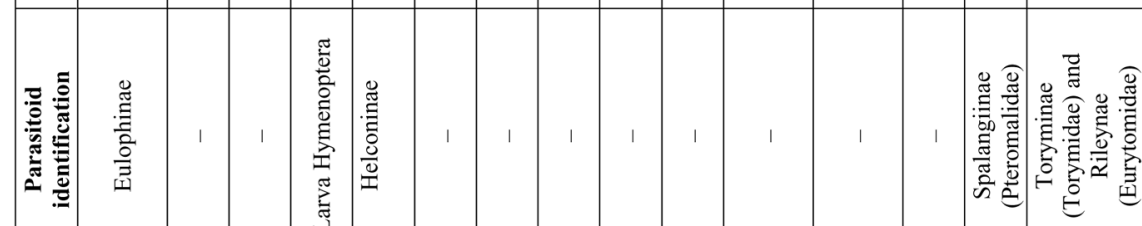

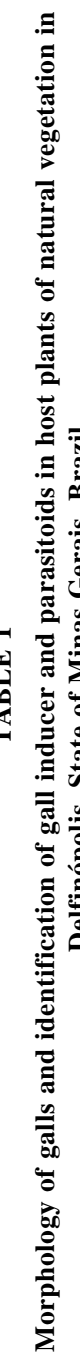

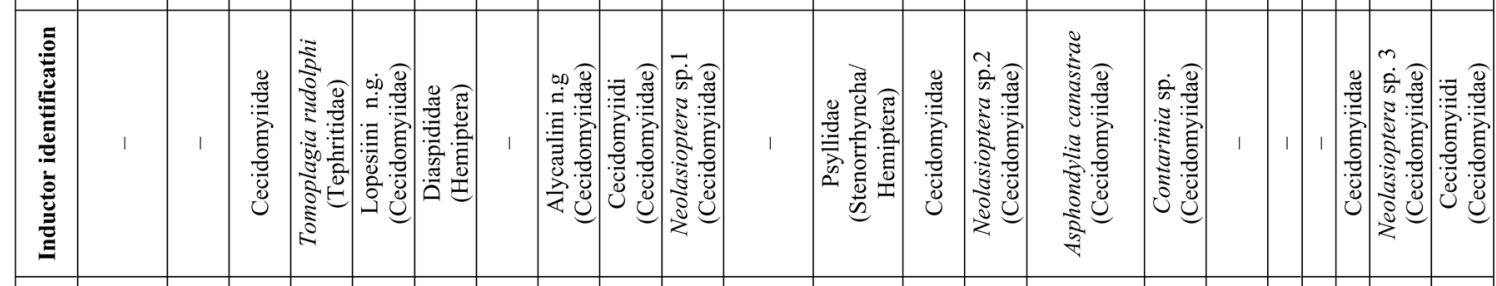

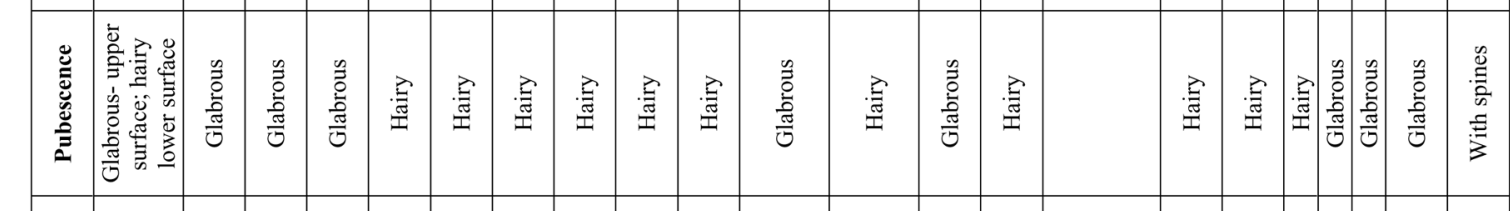

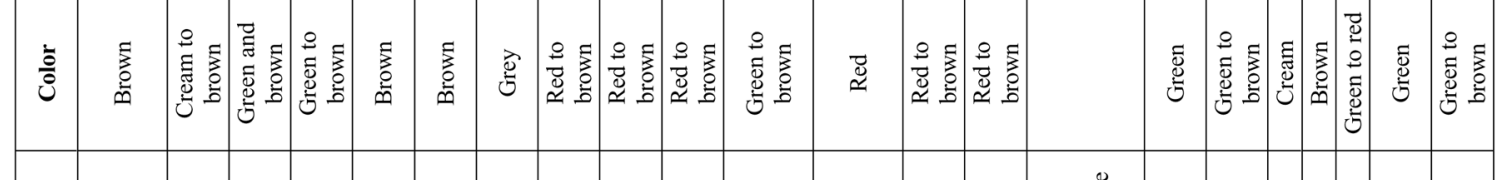

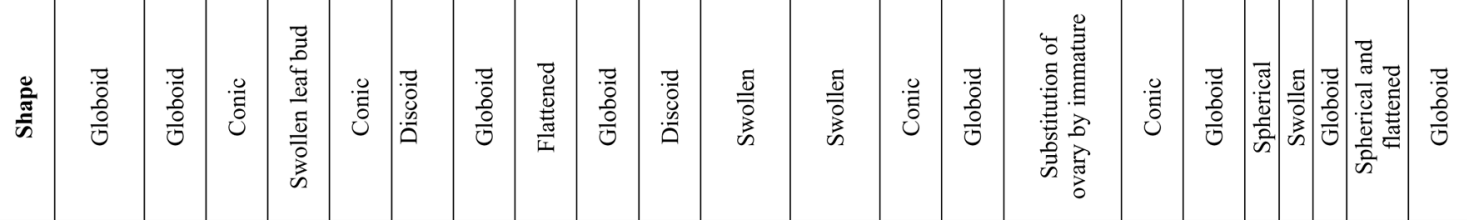

\begin{tabular}{|c|c|c|c|c|c|c|c|c|c|c|c|c|c|c|c|c|c|}
\hline & 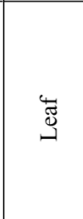 & 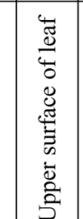 & 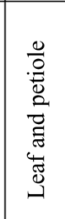 & 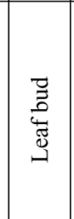 & 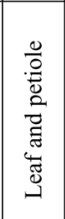 & 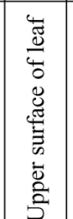 & 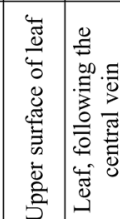 & 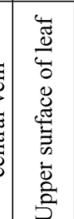 & 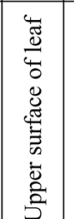 & 暿 & $\begin{array}{l}\bar{E} \\
\bar{s} \\
\bar{s}\end{array}$ & 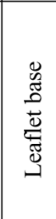 & 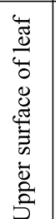 & 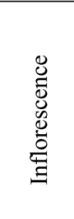 & 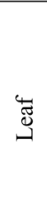 & 岁 & 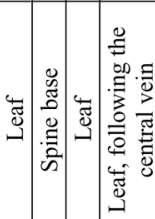 \\
\hline
\end{tabular}

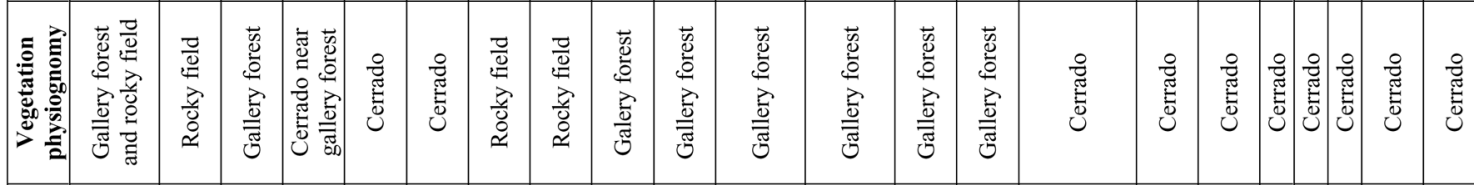

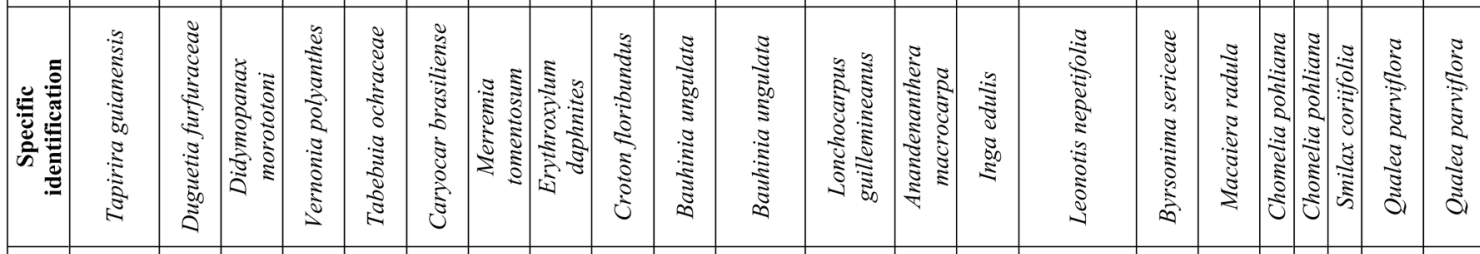

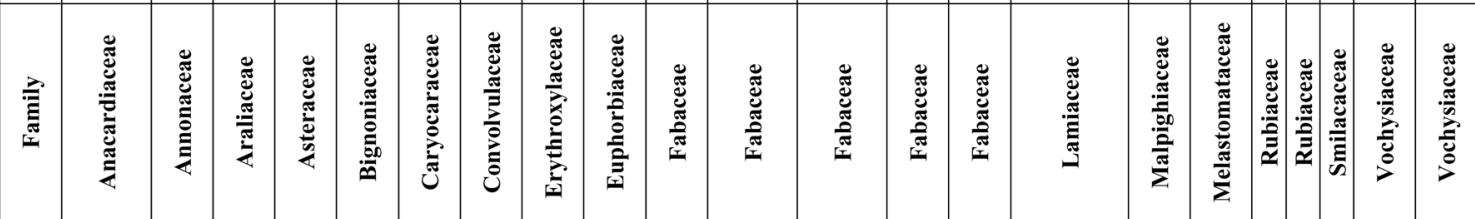


The presence of new species in the sampled areas indicates the importance of this kind of study to inventory the diversity present in open environments. Taxonomic novelties can help in elucidating biodiversity patterns, so essential for identifying and conserving endemism and hotspot areas.

Acknowledgments - The authors wish to thank Carmem Sílvia Lazzarini da Silva and Francisco Paulo da Silva for authorizing samples collection in a private area; Dra. E. M. Varanda, Dr. D. S. Amorim, Dra. S. A. P de Godoy, and Dr. R. Zucchi; the technician M. I. P. A. Balbi and MSc. Olga Kotchetkoff-Henriques (Depto Biologia/FFCLRP/USP); Dr. R. J. Gagné (SEL/BARC/USDA/ Smithsonian Institution); MSc. R. Romero (Herbarium/UFU); and CAPES and FAPESP (Proc.\# 99/05629-5 e 99/01429-1).

\section{REFERENCES}

ABRAHAMSON, W. G. \& McCREA, K. D., 1986, The impacts of galls and gall makers on plants. Proc. Entomol. Soc. Wash., 88: 364-367.

ABRAHAMSON, W. G., MELIKA, G., SCRAFFORD, R. \& CSOKA, G., 1998, Gall-inducing insects provide insights into plant systematic relationships. American Journal of Botany, 85(9): 1159-1165.

BATALHA, M. A. \& MANTOVANI, W., 2000, Reproductive phenological patterns of cerrado plant species at the Péde-Gigante Reserve (Santa Rita do Passa Quatro, SP, Brazil): a comparison between the herbaceous and woody floras. Rev. Bras. Biol., 60: 129-145.

BERTANI, D. F., RODRIGUES, R. R., BATISTA, J. L. F. \& SHEPHERD, G. J., 2001, Análise temporal da heterogeneidade florística e estrutural em uma floresta ribeirinha. Rev. Bras. Bot., 24: 11-23.

EMBRAPA, 1999, Sistema brasileiro de classificação de solo. Serviço de Informação - SPI, 2. reimpress., Brasília, 412p.

FERNANDES, G. W. A., TAMEIRÃO-NETO, E. \& MARTINS, R. P., 1988, Ocorrência e caracterização de galhas entomógenas na vegetação do campus Pampulha da Universidade Federal de Minas Gerais. Rev. Bras. Zool., 5: 11-29.

FERNANDES, G. W. \& PRICE, W. P., 1991, Comparisons of tropical and temperate galling species richness: The roles of environmental harsh and plant nutrient status. In: W. P. Price, T. M. Lewinsohn \& G. W. Fernandes (eds.), Plant animal interactions: evolutionary ecology in tropical and temperate regions. Wiley and Sons, New York, USA, pp. 91-115.

FERNANDES, G. W., CARNEIRO, M. A. A., LARA, A. C. F., ALLAIN, L. R., ANDRADE, G. I., JULIÃO, G. R., REIS, T. R. \& SILVA, I. M., 1996, Galling insects on Neotropical species of Baccharis (Asteraceae). Trop. Zool., 9: 315-332.

FERNANDES, G. W., ARAÚJO, R. C., ARAÚJO, S. C., LOMBARDI, J. A., PAULA, A. S., LOYOLA Jr., R. \& CORNELISSEN, T. G., 1997, Insect galls from savanna and rocky fields of the Jequitinhonha Valley, Minas Gerais, Brasil. Naturalia, 22: 221-224.
GAGNÉ, R. J., 1994, The gall midges of the neotropical region. Cornell University Press, Ithaca, New York, xi e 352p.

GIULIETTI, A. M., MENEZES, N. L., PIRANI, J. R., MEGURO, M. \& WANDERLEY, M. G. L., 1987, Flora da Serra do Cipó, Minas Gerais: caracterização e lista das espécies. Boletim de Botânica, 9: 1-152.

GONÇALVES-ALVIM, S. J. \& FERNANDES, G. W., 2001, Biodiversity of galling insects: historical, community and habitat effects in four Neotropical savannas. Biodiv. Cons., 10: 79-98

GULLAN, P. J. \& CRANSTON, P. S., 1994, The insects an outline of entomology. Chapman and Hall, London, Reino Unido, 491p.

HARTLEY, S. E., 1998, The chemical composition of plant galls: are levels of nutrients and secondary compounds controlled by the gall-formed? Oecologia, 113: 492-501.

MANI, M. S., 1964, Ecology of plant galls. W. Junk, The Hague, xii e $434 \mathrm{p}$.

NIMER, E., 1989, Climatologia do Brasil. 2. ed. Instituto Brasileiro de Geografia e Estatística, Rio de Janeiro, 421p.

OCCHIONI, P., 1979, "Galhas", "cecídeas" ou "tumores vegetais" em plantas nativas da flora do Brasil. Leandra, 8/9: 5-35.

OCCHIONI, P., 1981, "Galhas", "cecídeas" ou "tumores vegetais" em plantas nativas da flora do Brasil. Leandra, 10/11: 131-139.

OLIVEIRA-FILHO, A. T., SCOLFORO, J. R. S. \& MELLO, J. M., 1994, Composição florística e estrutura comunitária de um remanescente de floresta semidecídua montana em Lavras, MG. Rev. Bras. Bot., 17: 167-182.

RIBEIRO, J. F. \& WALTER, B. N. T., 1998, Fitofisionomias do bioma cerrado. In: S. M. Sano \& S. P. Almeida (eds.), Cerrado: ambiente e flora. EMBRAPA Cerrados, Brasília, pp. 88-166.

RIZZINI, C. T., 1979, Tratado de fitogeografia do Brasil. Aspectos sociológicos e florísticos. HUCITEC, São Paulo, 2: 374.

ROHFRITSCH, O. \& SHORTHOUSE, J. D., 1982, Insect galls. In: G. Kahls \& J. S. Schell (eds.), Molecular biology of plant tumors. Academic Press, New York, USA, pp. 131152.

SCARELLI-SANTOS, C. \& URSO-GUIMARÃES, M. V., submitted, Occurrence and characterization of insect galls in host plants of Pé-de-Gigante Cerrado Reserve, Santa Rita do Passa Quatro, SP, Brazil. International Journal of Plant Sciences.

URSO-GUIMARÃES, M. V. \& AMORIM, D. S., in press, New Brazilian species of Asphondyliini (Diptera: Cecidomyiidae). Revista Brasileira de Entomologia.

VAN DEN BERG, E. \& OLIVEIRA-FILHO, A. T., 2000, Composição florística e estrutura fitossociológica de uma floresta ripária em Itutinga, MG, e comparação com outras áreas. Rev. Bras. Bot., 23: 231-253. 


\section{APPENDIX 1}

\section{DATA ON CECIDOMYIIDAE GALLS OR DAMAGE}

\section{Tapirira guianensis Aubl. (Anacardiaceae)}

Registration number: 366/2000; 375/2000; 376/2000 (Urso-Guimarães, MV \& Scareli-Santos, C. leg.).

Distribution: Brazil (from Pará to Rio Grande do Sul, in many types of vegetation).

Gall (Fig. 4). Leaf gall, globoid, closed, hairy and red to brown in upper surface and glabrous and green in lower surface. Diameter: $\pm 0.3 \mathrm{~cm}$. Number of galls/leaf: 1-20. Periods of gall occurrence: JuneJuly. Points of occurrence: gallery forest and rocky field. Comments: the first report of galls in $T$. guianensis for the neotropical region.

\section{Duguetia furfuracea (A. St.-Hil.) Benth. \& Hook.} f. (Annonaceae)

Registration number: 367/2000; 373a/2000 (Urso-Guimarães, MV \& Scareli-Santos, C. leg.). Distribution: Brazil.

Gall (Fig. 5). Leaf gall, globoid, closed, frequently in groups of galls. The gall is cream to brown, glabrous, and present exclusively in the upper surface. Diameter: $\pm 0.3 \mathrm{~cm}$. Points of occurrence: gallery forest and rocky field. Number of galls/leaf: 1-10. Periods of gall occurrence: June-July.

\section{Didimopanax morototoni (Aubl.) Decne. \& Planch (Araliaceae) \\ Registration number: 1111/2000 (Scareli- Santos, C. leg.). \\ Distribution: Brazil (from the Amazon region} to Rio Grande do Sul, in many types of vegetation) Gall (Fig. 6). Leaf and petiole gall, globoid, it corresponds to swollen leaf or petiole, closed, glabrous, and green to brown in both surface of leaf and at the base of petiole. Frequently in groups. Diameter: $\pm 0.4 \mathrm{~cm}$. Number of galls/leaf: $1-50$. Number of larvae/gall: 1. Periods of gall occurrence: March-June. Points of occurrence: cerrado. Comments: the first report of galls in Didimopanax morototoni for Minas Gerais State. Urso-Guimarães \& Amorim (in press) are describing a new species of Asphondylia to Didymopanax morototoni in Ribeirão Preto, State of São Paulo.

\section{Vernonia polyanthes Less. (Asteraceae)}

Registration number: 368/2000 (Urso-Guimarães, MV \& Scareli-Santos, C. leg.).

Distribution: Brazil.

Gall (Fig. 7). Swollen bud leaf, green, glabrous, at tip of plant. Length: $\pm 1.4 \mathrm{~cm}$, width: $\pm 0.6 \mathrm{~cm}$. Number of galls/leaf: 1. Gall maker: Tephritidae. Pupation in gall. Locality: cerrado near gallery forest. Material: 2 adults (11.vii.2000), 1 gall (29.vi.2000). Periods of gall occurrence: June-July. Points of occurrence: Estancia Carmen Sílvia (cerrado near gallery forest). Comments: this plant gall-gall maker relationship was related by Fernandes et al. (1988).

\section{Tabebuia ochracea (Cham.) Standl. (Bignoniaceae)} Registration number: 1010/2000 (ScareliSantos, C. leg.).

Distribution: Brazil (Mato Grosso do Sul, Goiás, Minas Gerais, São Paulo, and Paraná states, in the cerrado and semideciduous forest).

Gall (Fig. 8). Leaf and petiole conic, hairy, and brown galls. Length: $\pm 0.3 \mathrm{~cm}$, width: $\pm 0.6 \mathrm{~cm}$ Number of galls/leaf: 1-20. Number of galls/petiole: 1-5. Gall maker: new genus of Lopesiini. Material: 10 larvae. Periods of gall occurrence: May-July. Points of occurrence: gallery forest and rocky field.

\section{Caryocar brasiliense Cambess (Caryocaraceae)} Registration number: 386a/2000 (Urso-Guimarães, MV \& Scareli-Santos, C. leg.).

Distribution: Brazil (São Paulo, Minas Gerais, Mato Grosso do Sul, Goiás, and Mato Grosso states, in the cerrado formation).

Gall (Fig. 9). Leaf gall, discoid, closed, hairy, brown in the upper leaf surface. Diameter: \pm 0.4 $\mathrm{cm}$. Number of galls/leaf: 1-20. Gall maker: Diaspididae (Hemiptera). Pupation in gall. Periods of gall occurrence: June-July. Points of occurrence: rocky field.

\section{Merremia tomentosa (Choisy) Hallier (Convolvu- laceae)}

Registration number: 372/2000 (Urso-Guimarães, MV \& Scareli-Santos, C. leg.).

Distribution: Brazil.

Gall (Fig. 10). Globoid, grey, hairy, and in the upper surface of leaves. Diameter: $\pm 0.4 \mathrm{~cm}$. Number of galls/leaf: 1-10. 30 galls (30.vi.2000). 
Periods of gall occurrence: March to December. Points of occurrence: gallery forest and rocky field.

\section{Erythroxylum daphnites (Choisy) Hallier (Erythroxylaceae)}

Registration number: 374/2000; 377/2000; 378/2000 (Urso-Guimarães, MV \& Scareli-Santos, C. leg.).

Distribution: Brazil.

Gall (Fig. 11). Hairy in the upper surface of leaf, glabrous in the lower surface, hair red to brown, following the central vein of leaf. Length: $\pm 3 \mathrm{~cm}$, width: $\pm 2 \mathrm{~cm}$. Number of galls/leaf: 1 . Number of larvae/locus: 1-100. Gall maker: Cecidomyiidae. Pupation in gall. Material : 70 exuviae (30.vi.2000). Periods of gall occurrence: June-July. Points of occurrence: cerrado and rocky field.

\section{EUPHORBIACEAE}

\section{Croton floribundus Spreng}

Registration number: 362/2000; 363/2000; 383/2000 (Urso-Guimarães, MV \& Scareli-Santos, C. leg.).

Distribution: Brazil (Rio de Janeiro, Minas Gerais, São Paulo, and Paraná states, in semideciduous forest).

Gall (Fig. 12). Leaf gall, globoid, closed, cream to brown, hairy. Diameter: $\pm 0.4 \mathrm{~cm}$. Number of galls /leaf: 1-50. Gall maker: pupation in gall. Periods of gall occurrence: June-July. Points of occurrence: gallery forest

\section{Bauhinia ungulata L. (Fabaceae, Caesalpinioidae)}

Registration number: 365/2000 (Urso-Guimarães, MV \& Scareli-Santos, C. leg.).

Distribution: Brazil (Rio de Janeiro and Minas Gerais until Rio Grande do Sul states).

Points of occurrence: gallery forest.

Gall (365/2000) (Fig. 13). Discoid and hairy in the upper surface of leaf, glabrous in the lower surface, hair red to brown. Diameter: $\pm 0.8 \mathrm{~cm}$. Number of galls/leaf: 1-10. Gall maker: Neolasioptera sp. n. Material: larvae. Periods of gall occurrence: June-July.

Gall (Fig. 14). Swollen petiole galls, glabrous, green to brown. Number of galls: 1. Material: 1 gall. Periods of gall occurrence: June-July.

\section{FABACEAE (FABOIDAE)}

\section{Lonchocarpus guillemineanus (Tul.) Malme}

Registration number: 361/2000 (Urso-Guimarães, MV \& Scareli-Santos, C. leg.).

Distribution: Brazil (Rio de Janeiro, Minas Gerais, São Paulo, and Paraná states, in semideciduous forest).

Gall (Fig. 15). Projections over the leaf vein galls, green, glabrous, closed, with the dehiscence along the distal part of gall. Length: $\pm 0,7 \mathrm{~cm}$, high: $\pm 0.4 \mathrm{~cm}$. Number of galls/leaf: 1-10. Gall maker: Psyllidae. Pupation in gall. Material: 10 adults. Periods of gall occurrence: June-July. Points of occurrence: gallery forest.

\section{Anadenanthera macrocarpa (Benth.) Brenan (Fabaceae, Mimosoidae)}

Registration number: 1521/2000 (ScareliSantos, C. leg.).

Distribution: Brazil (São Paulo, Minas Gerais, Mato Grosso do Sul, and Goiás states, in the cerrado formation).

Gall (Fig. 16). Conic leaflet galls, glabrous, in the upper surface at the base of leaflets. Length: $\pm 0.7 \mathrm{~cm}$, width: $\pm 0.3 \mathrm{~cm}$ and long: $\mathrm{cm}$. Number of galls/leaflet: 1. Gall maker: Cecidomyiidae. Pupation in soil. Material: larvae. Other arthropods associated: Hymenoptera. Periods of gall occurrence: April-July. Points of occurrence: cerrado. Comments: pupation in soil consists in indirect information. Emergence of adults never could be observed, because larvae always dropped to the bottom of pots where the stems with galls remained until emergence.

\section{Inga edulis Mart (Fabaceae, Mimosoidae)}

Registration number: 360/2000 (Urso-Guimarães, MV \& Scareli-Santos, C. leg.).

Distribution: Brazil (from São Paulo to Rio Grande do Sul states, in gallery and ciliary forest). Gall (Fig. 17). Discoid and hairy in the upper surface of leaf, glabrous in the lower surface, hair red to brown. Diameter: $\pm 0.5 \mathrm{~cm}$. Number of galls/ leaf: 1-10. Inquiline: Meunieriella sp.n. Cecidomyiidae). Pupation in gall. Material: 6 males, 2 females, and 3 pupa exuviae (15.viii.2000); 20 galls (29.vi.2000). Other arthropods associated: Hymenoptera. Periods of gall occurrence: June-July. 
Points of occurrence: Gallery forest. Comments: The inductor of galls in Inga edulis was not found. Meunieriella is a very well known inquiline genera in the neotropical region; it belongs to the Camptoneuromyiini tribe in which all genera are inquilines.

\section{Leonotis nepetifolia (L.) R. Br. (Lamiaceae)}

Registration number: 367/2000; 373/2000

(Urso-Guimarães, MV \& Scareli-Santos, C. leg.).

Distribution: Brazil.

Gall (Fig. 18). Occupation of inflorescence ovary by larvae. Number of galls/flower: 1. Gall maker: Asphondylia canastrae. Pupation in gall. Material: 2 males (11.vii.2000 and 13.vii.2000), 1 female (12.vii.2000), 4 pupae, and 5 pupa exuviae. Other arthropods associated: Hymenoptera (11.vii.2000). Periods of gall occurrence: June-July. Points of occurrence: Cerrado. Comments: UrsoGuimarães \& Amorim (in press) have described Asphondylia canastrae.

\section{Byrsonima sericea DC. (Malpighiaceae)}

Registration number: 1446/2000 (ScareliSantos, C. leg.).

Distribution: Brazil (Ceará, Rio de Janeiro, and Pernambuco states); Bolivia (Santa Cruz).

Gall (Fig. 19). Projections in the lower surface of leaf, conic, closed, green, hairy. Length: \pm 0.3 $\mathrm{cm}$, width: $\pm 0.5 \mathrm{~cm}$. Number of galls/leaf: 1-20. Gall maker: Contarinia sp. Material: larvae. Periods of gall occurrence: March-July. Points of occurrence: gallery forest and rocky field.

\section{Macairea radula (Bompl.) DC. (Melastomataceae)} Registration number: 382/2000 (Urso-Guimarães, MV \& Scareli-Santos, C. leg.).

Distribution: Brazil.

Gall (Fig. 20). Leaf gall, globoid, hairy, green to brown, Diameter: $\pm 0.3 \mathrm{~cm}$. Number of galls/leaf: 1-10. Periods of gall occurrence: June-July. Points of occurrence: cerrado.

Chomelia pohliana M Müll. Arg. (Rubiaceae)

Registration number: 367/2000; 373/2000

(Urso-Guimarães, MV \& Scareli-Santos, C. leg.).
Distribution: Brazil: (Goiás and Minas Gerais states).

Gall (Fig. 21). Discoid and hairy in the upper surface of leaf, glabrous in the lower surface, hair cream. Diameter: $\pm 0.3 \mathrm{~cm}$. Number of galls/leaf: 1-10. Periods of gall occurrence: June-July. Points of occurrence: gallery forest and rocky field.

\section{Smilax coriifolia A. DC. (Smilacaeae)}

Registration number: 373b/2000 (Urso-Guimarães, MV \& Scareli-Santos, C. leg.).

Distribution: Brazil (Minas Gerais, São Paulo)

Gall (Fig. 22). Leaf globoid gall, glabrous, green to red. Diameter: $\pm 0.3 \mathrm{~cm}$. Number of galls/ leaf: 1-10. Gall maker: Cecidomyiidae. Pupation in gall, associated with fungus. Material: larvae (30.vi.2000). Other arthropods associated: Hymenoptera. Periods of gall occurrence: June-July. Points of occurrence: cerrado.

\section{Qualea parviflora Mart. (Vochysiaceae)}

Registration number: 367/2000; 373/2000

(Urso-Guimarães, MV \& Scareli-Santos, C. leg.).

Distribution: Brazil (Bahia, Minas Gerais, Mato Grosso do Sul, São Paulo states, only in cerrado formation).

Points of occurrence: cerrado.

Gall (Fig. 23). Globoid leaf gall, following the central vein, green, glabrous. Diameter: \pm 0.5 $\mathrm{cm}$. Number of galls/leaf: 1-10 Gall maker: Neolasioptera sp. Material: 3 larvae (1ºvii.2000). Periods of gall occurrence: June-July.

Gall (Fig. 24). Globoid leaf galls, with spines all around the gall, green to brown. Diameter: \pm 0.3 $\mathrm{cm}$. Number of galls/leaf: 1-5. Gall maker: Cecidomyiidi. Material: 3 larvae (1 ${ }^{\circ}$.vii.2000) Periods of gall occurrence: June-July.

Note: All plant species names and distribution were checked in the Lorenzi book (1992) and/or on the site of the Missouri Botanical Gardens in the VAST (VAScular Tropicos) database, located at the electronic address: http://mobot.mobot.org/W3T/ Search/vast.html. 